\title{
Pemodelan dan Simulasi Sistem Industri Manufaktur Menggunakan Metode Simulasi Hybrid (Studi Kasus: PT. Kelola Mina Laut)
}

\author{
Muhammad Alam Pasirulloh dan Erma Suryani \\ Departemen Sistem Informasi, Fakultas Teknologi Informasi, Institut Teknologi Sepuluh Nopember \\ (ITS) \\ e-mail: derma.suryani@gmail.com
}

\begin{abstract}
Abstrak - Proses pengolahan dan pengawetan ikan merupakan salah satu bagian penting dari industri perikanan. Tanpa adanya kedua proses tersebut, peningkatan produksi ikan akan sia-sia, karena tidak semua produk perikanan dapat dimanfaatkan oleh konsumen dalam keadaan baik. Pengolahan dan pengawetan bertujuan mempertahankan mutu dan kesegaran ikan selama mungkin. Ikan hasil pengolahan dan pengawetan umumnya sangat disukai oleh masyarakat karena produk akhirnya mempunyai ciri-ciri khusus yakni perubahan sifat-sifat daging seperti bau, rasa, bentuk, dan tekstur. Pengelolaan sumber daya perikanan dan kelautan memang dihadapkan pada suatu sistem yang cukup kompleks. Kompleksitas itu terjadi, baik dari sistem sumber daya alam sendiri maupun interaksi antara sistem sumber daya alam dengan aspek manusia. Oleh karena itu permasalahan pengelolaan sumber daya perikanan,pengelolaan, dan pembangunan, sumber daya perikanan masih dirasakan relatif kompleks. Salah satu metode yang dapat digunakan untuk melakukan optimalisasi adalah dengan menggunakan pemodelan dan simulasi sistem, yang mana simulasi sistem yang digunakan adalah simulasi hybrid. Simulasi hybrid adalah kombinasi dari simulasi dinamik dan simulasi diskrit. Penggunaan simulasi hybrid ini cocok digunakan dalam proses produksi KML FOOD, karena produksi surimi based product, menggunakan mesin otomatis dan menggunakan tenaga manusia. Simulasi hybrid juga dapat menjelaskan masing-masing kelebihan dari setiap simulasi, yang mana simulasi diskrit memiliki scope di bagian operasional sementara simulasi dinamik di bagian strategi. Skenario baru dalam simulasi optimal yang dihasilkan diharapkan memiliki pengukuran manajemen waktu dan biaya lebih baik, sehingga meningkatkan sistem produksi dari KML FOOD. Hasil dari studi adalah dokumentasi rekomendasi model skenario alternatif berbasis simulasi dinamis yang dapat meningkatkan manajemen waktu dan nilai biaya minimal dalam proses produksi KML FOOD.
\end{abstract}

Kata Kunci—Hybrid, Simulasi, Produksi, Sistem Dinamik, Sistem Diskrit.

\section{PENDAHULUAN}

$\mathrm{P}$ ROSES pengolahan dan pengawetan ikan merupakan salah satu bagian penting dari industri perikanan. Tanpa adanya kedua proses tersebut, peningkatan produksi ikan akan sia-sia, karena tidak semua produk perikanan dapat dimanfaatkan oleh konsumen dalam keadaan baik. Pengolahan dan pengawetan bertujuan mempertahankan mutu dan kesegaran ikan selama mungkin. Ikan hasil pengolahan dan pengawetan umumnya sangat disukai oleh masyarakat karena produk akhirnya mempunyai ciri-ciri khusus yakni perubahan sifat-sifat daging seperti bau, rasa, bentuk, dan tekstur [1].

Pada era bisnis dan teknologi yang semakin berkembang ini, jenis-jenis atau variasi industri semakin banyak dijumpai. Industri tekstil,elektronika, emas dan lain-lain mengalami pertumbuhan yang cukup signifikan. Industri makanan dan minuman juga tidak lepas dari arus perkembangan ini. Industri makanan dan minuman menjadi 10 besar peran komoditi tertinggi di Indonesia yaitu sebesar 5,25\% dan menjadi cabang industri non migas kedua yang memiliki pertumbuhan terbaik sebesar 7,54\% [2]. Oleh sebab itu, industri makanan dan minuman menjadi titik vital industri non migas di Indonesia.

PT. Kelola Mina Laut (KML FOOD) perusahaan besar berskala internasional yang bergerak di bidang eksportir makanan laut, sayur-mayur hingga berbagai olahan ikan ke berbagai penjuru dunia mulai dari Amerika Serikat, Kanada, Eropa, Jepang, China, Australia, Afrika, dan masih banyak lagi. KML FOOD memiliki kapasitas produk hingga puluhan ribu ton setiap tahunnya untuk setiap jenis produk yang dibuat. Salah satu produk yang sudah menjadi ciri khas KML FOOD sejak tahun 2006 yaitu surimi based product memiliki kapasitas produksi hingga 30.000 ton per tahunnya [3]. KML FOOD memproduksi berbagai jenis surumi dengan menggunakan lini produksi otomatis dan bahan-bahan yang beragam untuk memenuhi kebutuhan pasar.

Manajemen produksi adalah salah satu inti proses bisnis dari Industri makanan dan minuman. Industri makanan dan minuman mayoritas menciptakan banyak dan berbagai macam produk tergantung dari kebutuhan target konsumen. Dengan berbagai kebutuhan pasar dan perencanaan produksi makanan dan minuman yang sangat kompleks sangat dibutuhkan manajemen produksi. Tujuan utama dari manajemen produksi adalah untuk memproduksi dengan kualitas yang tepat dan kuantitas yang benar di saat yang tepat dan biaya yang sesuai [4]. Dengan melakukan manajemen produksi ini diharapkan dapat meningkatkan efisiensi proses produksi dalam manajemen waktu dan minimalisasi biaya.

Pengelolaan sumber daya perikanan dan kelautan memang dihadapkan pada suatu sistem yang cukup kompleks. Kompleksitas itu terjadi, baik dari sistem sumber daya alam sendiri maupun interaksi antara sistem sumber daya alam dengan aspek manusia. Oleh karena itu permasalahan pengelolaan sumber daya perikanan,pengelolaan, dan pembangunan, sumber daya perikanan masih dirasakan relatif kompleks [5]. 
Salah satu metode yang dapat digunakan untuk melakukan optimalisasi adalah dengan menggunakan pemodelan dan simulasi sistem, yang mana simulasi sistem yang digunakan adalah simulasi hybrid. Simulasi hybrid adalah kombinasi dari simulasi dinamik dan simulasi diskrit. Penggunaan simulasi hybrid ini cocok digunakan dalam proses produksi KML FOOD, karena produksi surimi based product, menggunakan mesin otomatis dan menggunakan tenaga manusia. Simulasi hybrid juga dapat menjelaskan masing-masing kelebihan dari setiap simulasi, yang mana simulasi diskrit memiliki scope di bagian operasional sementara simulasi dinamik di bagian strategi [6]. Skenario baru dalam simulasi optimal yang dihasilkan diharapkan memiliki pengukuran manajemen waktu dan biaya lebih baik, sehingga meningkatkan efesiensi sistem produksi dari KML FOOD.

\section{DASAR TEORI}

\section{A. PT. Kelola Mina Laut}

PT. Kelola Mina Laut (KML FOOD) perusahaan besar berskala internasional yang bergerak di bidang eksportir makanan laut, sayur-mayur hingga berbagai olahan ikan ke berbagai penjuru dunia mulai dari Amerika Serikat, Kanada, Eropa, Jepang, China, Australia, Afrika, dan masih banyak lagi. KML FOOD memiliki kapasitas produk hingga puluhan ribu ton setiap tahunnya untuk setiap jenis produk yang dibuat. Salah satu produk yang sudah menjadi ciri khas KML FOOD sejak tahun 2006 yaitu surimi based product memiliki kapasitas produksi hingga 30.000 ton per tahunnya [3]. KML FOOD memproduksi berbagai jenis surumi dengan menggunakan lini produksi otomatis dan bahan-bahan yang beragam untuk memenuhi kebutuhan pasar.

Dalam sekali produksi surumi KML FOOD mendatangkan kurang lebih 50-70 ton ikan sebagai bahan baku produksi. Produksi surumi diatur oleh kantor pusat tergantung dari jumlah pesanan yang diterima. Setiap bagian produksi selalu dijaga kebersihannya yang mana setiap pekerja yang bekerja dalam bagian produksi harus mengenakan pakaian khusus dan menjalankan semua SOP yang telah ditetapkan oleh perusahaan. Lama waktu produksi dari bahan baku ikan datang di pabrik hingga masuk ke dalam tempat penyimpanan yang mana nantinya akan dilakukan pembungkusan produk jadi yang siap dijual kurang lebih 8-10 jam. Proses bisnis dari produksi surumi KML FOOD bisa dilihat dari ilustrasi gambar 1.

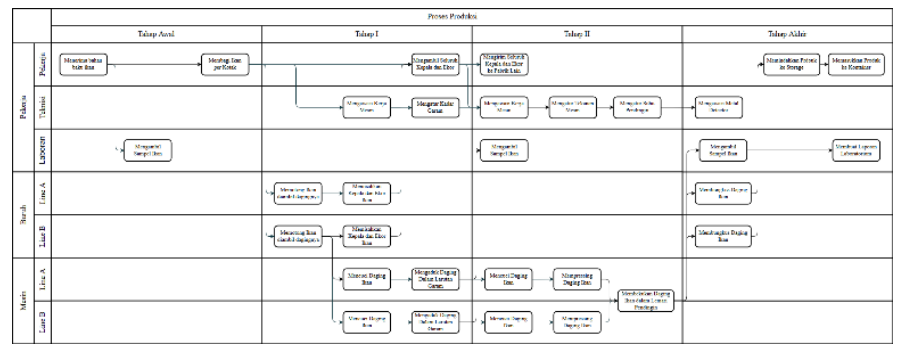

Gambar 1. Proses Produski Surumi KML Food

\section{B. Sistem Dinamik}

Sistem dinamik adalah metode yang digunakan untuk mempelajari, memahami dan memodelkan kebijakan publik dan privat, dan membantu meningkatkan pengambil keputusan. Model simulasi dinamik pertama kali dikembangkan oleh Jay Wright Forrester pada tahun 1950-an. Sistem dinamik menggunakan model simulasi untuk memahami dinamika perilaku sistem yang kompleks dan mendesain kebijakan yang lebih efektif.

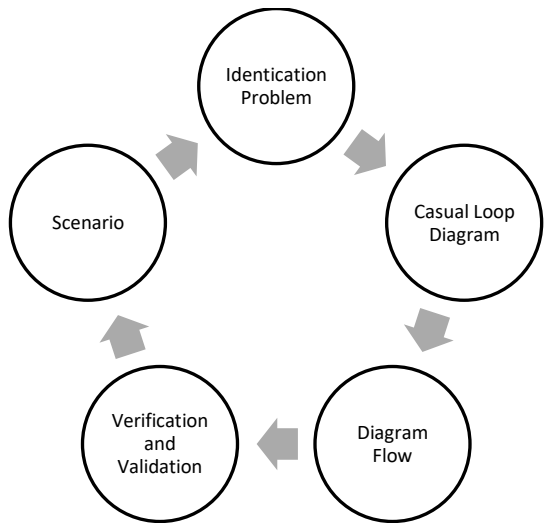

Gambar 2. Tahap Pemodelan Sistem Dinamik

\section{Sistem Diskrit}

Sistem diskrit adalah simulasi sistem yang mana perubahan dalam waktu yang terpisah, seperti dalam sistem manufaktur dimana bagian datang dan keluar di waktu yang spesifik, mesin mati dan hidup lagi di waktu yang spesifik, dan istirahat kerja bagi pekerja. Pemodelan simulasi sistem diskrit biasanya disebut jua dengan model simulasi sistem kejadian-diskrit (Discrete-Event Simulation Model, DES Model). Variabel waktu dan keadaan merupakan dua variabel penting yang digunakan untuk mendeskripsikan karakteristik model simulasi [7].

\section{Simulasi Hybrid}

Simulasi hybrid adalah model simulasi mengombinasikan dua simulasi yaitu simulasi sistem dinamik dan simulasi sistem diskrit. Pendekatan yang sangat berbeda dari sistem dinamik (SD) dan sistem diskrit (DES) saat memodelkan suatu proses, ternyata bisa digabungkan dengan melihat kedua simulasi tersebut menampilkan sudut pandang yang saling mendukung. Pendekatan SD lebih ditujukan untuk model keputusan strategis sementara DES untuk keputusan pada tingkat operasional [6]Tabel perbandingan dapat dilihat pada Tabel 1 . 
Tabel 1.

Perbandingan DES dengan SD

\begin{tabular}{|c|c|}
\hline DES & SD \\
\hline \multicolumn{2}{|c|}{ Problem } \\
\hline $\begin{array}{l}\text { Seeking to understand the } \\
\text { impact of randomness } \\
\text { on the system }\end{array}$ & $\begin{array}{l}\text { Aiming to understand the } \\
\text { feedback within the system } \\
\text { and its impact }\end{array}$ \\
\hline \multicolumn{2}{|c|}{ Scope } \\
\hline Operational & Strategic / Policy \\
\hline \multicolumn{2}{|c|}{ System } \\
\hline $\begin{array}{l}\text { High level of detail that } \\
\text { physically represents the } \\
\text { system (detail complexity) }\end{array}$ & $\begin{array}{l}\text { More macro level of detail } \\
\text { that summarises the system } \\
\text { (dynamic complexity) }\end{array}$ \\
\hline \multicolumn{2}{|c|}{ Methodology } \\
\hline Process view & Systems view \\
\hline \multicolumn{2}{|c|}{ Philosophy } \\
\hline Randomness & Feedback \\
\hline
\end{tabular}

Menurut chahal dan eldabi (2008) ada tiga tipe model simulasi hybrid: hierarchical, process - environment, dan integrated format. dalam tipe model hierarchical model SD bergerak dan memberikan acuan kepada model des sebagai data awal untuk model DES. saat model DES selesai dengan simulasinya hasilnya akan menjadi data pertimbangan untuk model SD

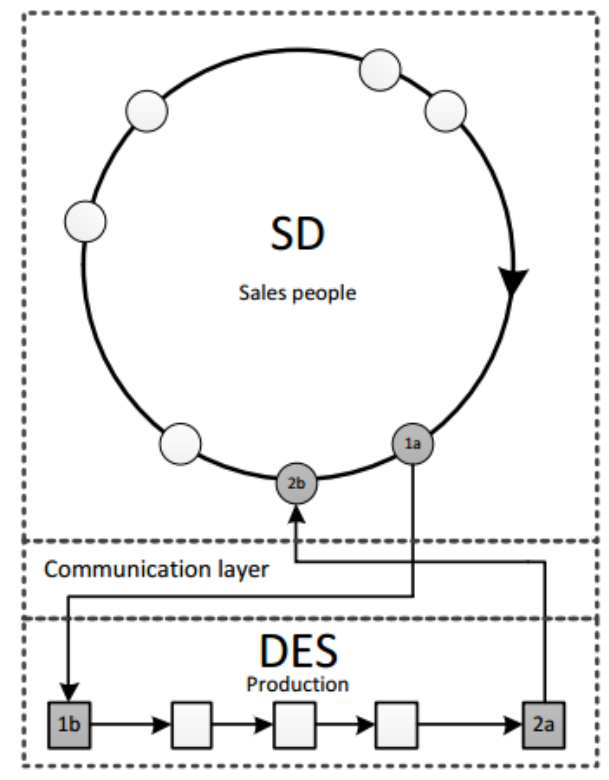

Gambar 3. Model Herarchical

\section{METODOLOGI}

Pengerjaan studi ini tersusun atas beberapa langkah yang sistematis.

\section{A. Analisis permasalahan}

Tahap analis permasalahan adalah tahap untuk melakukan analisis yang ada dalam proses produksi KML FOOD. Untuk mengetahui kondisi dalam proses produksi KML FOOD dilakukan proses wawancara dengan penanggung jawab produksi KML FOOD dan dilakukan pengamatan langsung di lokasi. Keluaran dari tahap ini adalah model proses yang terjadi sekarang yang dimodelkan dengan simulasi dinamis.

\section{B. Studi literatur}

Pada tahap studi literatur, penulis mengumpulkan informasi yang nantinya digunakan untuk mengusulkan solusi terkait dengan permasalahan yang ada. Pengumpulan data dan informasi sendiri dilakukan dengan cara membaca referensi dari buku dan penelitian-penelitian yang telah dilakukan sebelumnya. Tujuan dari tahap ini agar penulis dapat memahami dasar teori yang berhubungan dengan permasalahan dan dapat mempermudah dalam menemukan solusi yang tepat.

\section{Pemodelan}

Tahap pemodelan adalah menggambarkan model yang diinginkan yang dalam penelitian ini sudah didapatkan dari hasil wawancara dengan salah satu pihak penyelenggara. Dalam proses pemodelan menggunakan simulasi dinamis, dibantu dengan aplikasi VENSIM yang membantu proses pemodelan yang diinginkan. Keluaran dari tahap ini adalah sistem produksi dalam KML FOOD. Untuk proses yang lebih lengkapnya adalah sebagai berikut ini:

\section{Identifikasi proses produksi saat ini dalam KML FOOD}

Tahap identifikasi proses saat ini dilakukan dengan proses wawancara langsung dengan penanggung jawab produksi di KML FOOD, tahap ini mendapatkan hasil berupa prosesproses yang perlu dilakukan dalam produksi KML FOOD.

\section{Memodelkan proses produksi dalam KML FOOD saat ini.}

Memodelkan proses adalah tahapan untuk memodelkan proses ke dalam Casual Loop diagram, dari proses-proses yang perlu dilakukan berdasarkan hasil wawancara sebelumnya.

3. Merancang proses produksi KML FOOD yang diharapkan

Tahapan merancang proses adalah tahapan untuk merancang ulang proses yang telah ada sebelumnya, apa saja yang perlu untuk dikurangi, dan atau ditambahkan agar proses produksi lebih efisien.

\section{Memodelkan proses produksi KML FOOD redesign}

Sama dengan memodelkan proses sebelumnya, tahapan ini adalah memodelkan proses yang telah didesain. Menjadi Casual Loop diagram.

\section{Analisis Model}

Analis model adalah tahapan pengujian model yang telah dirancang. Target pengujian sendiri ditunjukkan kepada penanggung jawab produksi KML FOOD. Analisis model dilihat apakah model rekomendasi sudah dapat menjadi alternatif sistem proses produksi awal. Keluaran dari tahap ini adalah rekomendasi model alternatif yang lebih efisien dari model awal.

\section{Mensimulasikan model rekomendasi}

Mensimulasikan model rekomendasi adalah tahapan menjalankan model rekomendasi untuk dilakukan verifikasi dan validasi. Verifikasi digunakan untuk membuktikan bahwa hasil model yang dibuat sudah sesuai dengan rancangan model konsep dari sistem. Sedangkan validasi digunakan untuk melihat apakah model yang dibuat sudah sesuai dengan kenyataan atau tidak. 
2. Menganalisis perbandingan skenario awal dengan rekomendasi skenario

Menganalisis perbandingan adalah tahapan skenario awal dan skenario baru disandingkan untuk mengukur dan efisiensi. Dalam tahap ini fokus utama adalah dari manajemen waktu dan nilai biaya minimal dari skenario baru.

\section{E. Penyusunan studi}

Setelah semua proses dalam penelitian mengenai proses produksi dalam KML FOOD selesai dan skenario baru telah dianggap melampaui skenario awal, selanjutnya dimulailah proses penyusunan laporan studi. Keluaran dari tahap ini adalah sebuah dokumentasi pengerjaan studi penulis yang dibuat dalam sebuah buku.

\section{HASIL DAN ANALISIS}

\section{A. Tahap Perancangan Model Simulasi}

Model simulasi dirancang sesuai dengan karakteristik dari sistem nyata di mana kapasitas Resources dan penjadwalan tiap proses disesuaikan dengan sistem nyata. Tampilan model clausial loop diagram secara keseluruhan dapat dilihat pada Gambar 5 di bawah ini

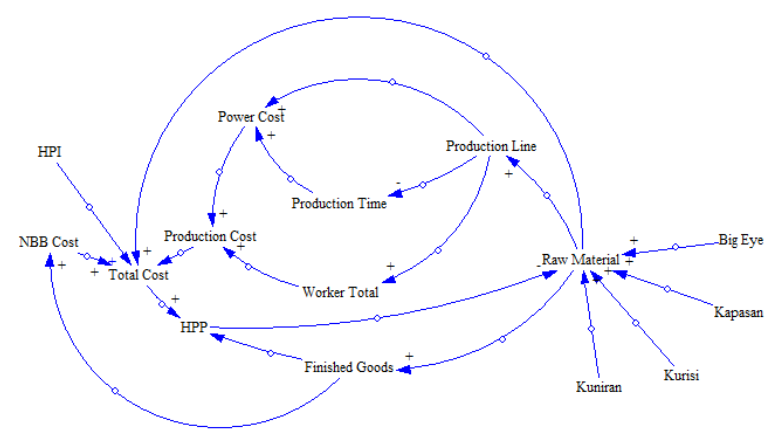

Gambar 5. CLD

Dari model CLD diatas dibuatlan stok overflow diagram yang menggambarkan sistem nyata. Untuk menggunakan metode simulasi hybrid selain dibutuhkan model dinamik dibutuhkan model diskrit juga. Model diskrit ini digunakan untuk memodelkan proses produksi secara detail dalam penggunaan Resources dan Waktu produksi.

\section{B. Perancangan dan Analisis Sistem Alternatif}

Dalam tahap ini adalah memodelkan sistem alternatif dan menganalisanya untuk mencapai tujuan penelitian.

1) Sistem Alternatif Pertama

Pada Sistem alternatif pertama penulis akan melakukan perubahan berupa:

1. Menambah jumlah Resources CPF menjadi 6 buah di dalam model sistem diskrit

2. Mengganti equation terhadap variabel CPF menyesuaikan perubahan pada sistem diskrit

3. Mengganti equation terhadap variabel production Time menyesuaikan hasil pada sistem diskrit

2) Sistem Alternatif Kedua

Pada Sistem alternatif kedua penulis akan melakukan perubahan berupa:
1. Mengganti struktur dalam sistem diskrit menjadi selalu memiliki 2 production line

2. Mengganti equation terhadap variabel production line menyesuaikan perubahan pada sistem diskrit

3. Mengganti equation terhadap variabel production Time menyesuaikan hasil pada sistem diskrit

4. Mengganti equation terhadap variabel worker menyesuaikan sistem diskrit

3) Sistem Alternatif Ketiga

Pada Sistem alternatif ketiga penulis akan melakukan perubahan berupa:

1. Menambah jumlah Resources CPF menjadi 6 buah di dalam model sistem diskrit.

2. Mengganti equation terhadap variabel CPF menyesuaikan perubahan pada sistem diskrit.

3. Mengganti equation terhadap variabel production Time menyesuaikan hasil pada sistem diskrit.

4. Mengganti struktur dalam sistem diskrit menjadi selalu memiliki 2 production line.

5. Mengganti equation terhadap variabel production line menyesuaikan perubahan pada sistem diskrit

6. Mengganti equation terhadap variabel production Time menyesuaikan hasil pada sistem diskrit

4) Hasil Uji Coba Sistem Alternatif

Evaluasi sistem alternatif akan dilakukan dengan perbandingan production Time (dari sistem diskrit) dan Harga Pokok Produksi (dari sistem dinamik). Hasilnya dapat dilihat pada Tabel 2.

Tabel 2.

Hasil Uji Coba Sistem Alternatif

\begin{tabular}{lrrrr}
\hline \hline Parameter & \multicolumn{1}{c}{ Sistem Nyata } & \multicolumn{1}{c}{ Skenario 1 } & \multicolumn{1}{c}{ Skenario 2 } & \multicolumn{1}{c}{ Skenario 3 } \\
\hline Time & 693.3 & 684.46 & 660.15 & 644.83 \\
HPP & 32462.52 & 32511.1 & 33077.14 & 33070.82 \\
\hline \hline
\end{tabular}

\section{Analis Hasil Uji Coba Sistem Alternatif}

Analisis hasil uji coba sistem alternatif akan dilakukan dengan membandingkan hasil masing-masing skenario dengan sistem nyata. Hasil perbandingan akan menjadi peningkatan atau pernurunan dalam persentase. Hasilnya semua dapat dilihat pada tabel 3 .

Tabel 3.

Perbandingan Sistem Alternatif dengan Sistem Nyata

\begin{tabular}{cccc}
\hline \hline Parameter & Skenario 1 & Skenario 2 & Skenario 3 \\
\hline Time & $1.28 \%$ & $4.78 \%$ & $6.99 \%$ \\
HPP & $0.15 \%$ & $1.86 \%$ & $1.84 \%$ \\
\hline \hline
\end{tabular}

Analisis hasil uji coba sistem alternatif dilihat dari dua parameter yaitu production Time dan HPP. Production Time dicari yang paling besar nilai peningkatannya, sementara untuk HPP dicari yang paling kecil nilai persentasenya.

\section{Penentuan Sistem Alternatif Terbaik}

Penenentuan sistem alternatif terbaik dilakukan melihat perbandingan pada Tabel 3, dimana Production Time dicari yang paling besar nilai peningkatannya, sementara untuk HPP dicari yang paling kecil nilai persentasenya. Berdasarkan tabel 3 diatas maka terlihat bahwa terjadi perbedaan signifikan antar skenario. Skenario 2 menjadi skenario yang paling buruk 
karena tidak memberikan peningkatan dari sisi waktu produksi meskipun nilai HPP naik secara signifikan yang mana akan merugikan pabrik dalam jangka panjang. Jadi skenario 2 tidak mungkin menjadi skenario terbaik. Hanya tersisa skenario 1 dan skenario 3. Jika dilihat dari hasil uji sistem alternatif kedua skenario maka diperoleh kesimpulan bahwa sistem alternatif ketiga yang terbaik dikarenakan sistem alternatif ketiga memperburuk nilai HPP hingga $1.84 \%$ sementara sistem alternatif pertama hanya $0.15 \%$. Untuk nilai parameter waktu produksi skenario ketiga mengalami peningkatan sangat signifikan yaitu $6.99 \%$. Kedua pernyataan ini menghasilkan kesimpulan bahwa sistem alternatif yang terbaik adalah sistem alternatif ketiga.

\section{KESIMPULAN}

Penelitian studi ini berhasil menganalisis waktu produksi total dari sistem nyata. Tiga buah sistem alternatif telah dirancang guna mengoptimasi sistem nyata dan setlah melalui proses analisis diputuskan bahwa sistem alternatif ketia adalah yang terbaik.

\section{SARAN}

Saran penulis untuk penelitian selanjutnya sebagai berikut:

1. Konsep dan model simulasi hybrid produksi pengolahan ikan ini dapat diterapkan di bagian sistem produksi pengelolaan lainnya.
2. Dari penelitian ini model simulasi bisa dikembangkan lebih baik lagi dengan menambah beberapa variabel mengenai pengadaan mesin baru untuk memperjelas skenario model simulasi diskrit.

3. Model simulasi hybrid sampai saat ini belum ada patokan jelas bagaimana cara membuatnya. Penelitian selanjutnya mungkin bisa membahas mendalam mengenai konsep simulasi hybrid berbanding dengan simulasi dinamik dan simulasi diskrit.

\section{DAFTAR PUSTAKA}

[1] E. A. and E. Liviawaty, Pengawetan Dan Pengolahan Ikan. Kanisius, 1989.

[2] K. P. R. Indonesia, Laporan Kinerja Kementerian Perindustrian Tahun 2015. 2016.

[3] "KML Food," 2016. [Online]. Available: http://kmlfood.com/home. [4] S. A. K. and N. Suresh, Production and Operations Management. New Delhi: New Age International (P) Ltd., 2008.

[5] A. F. and S. Anna, Pemodelan Sumber Daya Perikanan dan Kelautan. Gramedia Pustaka Utama, 2005.

[6] and G. L. B. Jovanovski, R. Minovski, S. Voessner, "Combining system dynamics and discrete event simulations - Overview of hybrid simulation models," J. Appl. Eng. Sci, vol. 10, no. 3, pp. 135-142, 2012.

[7] and D. T. S. W. D. Kelton, R. P. Sadowski, Simulation with Arena. McGraw-Hill, 2007. 